\title{
Working ability and coronary heart disease
}

\section{Zrinka Alfirević*, Katija Barać}

Institute for the expertise, professional rehabilitation and employment of persons with disabilities, Zagreb, Croatia
RECEIVED:

September 15, 2015 ACCEPTED:

September 17, 2015

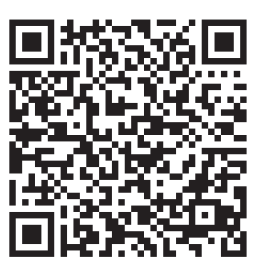

KEYWORDS: coronary heart disease, exercise test, work ability/disability.

CITATION: Cardiol Croat. 2015;10(9-10):218. | DOI: http://dx.doi.org/10.15836/ccar.2015.218

*ADDRESS FOR CORRESPONDENCE: Zrinka Alfirević, Zavod za vještačenje, profesionalnu rehabilitaciju i zapošljavanje osoba s invaliditetom, Mihanovićeva 3, HR-10000 Zagreb, Croatia. / Phone: +385-98-417-307

E-mail: zrinka.alfirevic@mirovinsko.hr

ORCID: Zrinka Alfirević, http://orcid.org/0000-0001-5604-7279 • Katija Barać, http://orcid.org/0000-0002-9231-3762

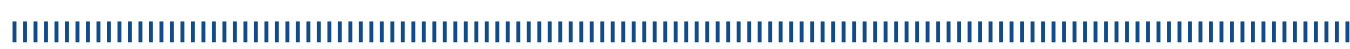

Coronary heart disease causes more deaths and disability and incurs greater economic costs than any other illness in the developed world. It is logical that this impact reflects on the working capacity of the individual. The frequency of returning to work varies greatly in the world, depending on the type of health insurance, duration of rent, the labor market and sick listing traditions among physicians.

The aim of modern therapy is to improve quality of life and the renewal of professional activity.

Work ability depends on the hearth conditions and circumstances of the workplace. Presence of chest pain during exercise, risk of arrhythmia and a high level of left ventricular dysfunction are the main symptoms indicating a working disability.

The most reliable test for assessing work capacity is the exercise test, but the results of this test should always be carefully analyzed. Functional assessment of the heart muscle is not always based on a strictly scientific basis, varying from examiner to examiner. The authors proposed when assessing coronary reserve that the upper general tolerance limit over on 8 hour work day consisting of mixed physical labor including manual handling operations, should be $40-45 \% \mathrm{VO}_{2}$ max. while exposure to short-time work extension may be allowed $70-80 \%$ of the end-point level of the exercise test.

The assessment should take into account that persons who take up active work after a myocardial infarction have a longer life span, a five times smaller percentage of neurosis and depression in relation to retired reconvalescents, and a significantly lower probability of developing a recurrent cardiac incident. Most often return to work the younger age groups, highly educated, highly educated, employed preoperatively. . $^{1-4}$

Assessments of working abilities should be made after the completion of treatment and rehabilitation, while taking into account all of the parameters so as not to harm the truly disabled.

LITERATURE IIIIIIIIIIIIIIIIIIIIIIIIIIIIIIIIIIIIIIIIIIIIIIIIIIIIIIIIIIIIIIIIIIIIIIIIIIIIIIIIIIIIIIIIIIIIIIIIIIIIIII

1. Lundbom J, Myhre HO, Ystgaard B, Aakhus S, Tromsdal A, Sudbø R, et al. Exercise tolerance and work ability following aorto-coronary bypass surgery. Scand J Soc Med. 1994;22(4):303-8. DOI: http://dx.doi.org/10.1177/140349489402200410

2. Waszkowska M, Szymczak W. Return to work after myocardial infarction: a retrospective study. Int J Occup Med Environ Health. 2009;22(4):37381. DOI: http://dx.doi.org/10.2478/v10001-009-0033-4

3. Selliera P, Varaillac P, Chatellier G, D'Agrosa-Boiteux MC, Douard H, Dubois C, et al. Factors in »uencing return to work at one year after coronary bypass graft surgery: results of the PERISCOP study. Eur J Cardiovasc Prev Rehabil. 2003;10(6):469-75.

DOI: http://dx.doi.org/10.1097/01.hj..0000106837.97722.86

4. Mirmohammadi SJ, Sadr-Bafghi SM, Mehrparvar AH, Gharavi M, Davari MH, Bahaloo M, et al. Evaluation of the return to work and its duration after myocardial infarction. ARYA Atheroscler. 2014;10(3):137-40. PubMed: http://www.ncbi.nlm.nih.gov/pubmed/25161683 